\title{
Short Communication Elevated protein kinase $C$ alpha expression may be predictive of tamoxifen treatment failure
}

\author{
DA Tonetti",, M Morrow ${ }^{2}$, N Kidwai ${ }^{3}$, A Gupta $^{3}$ and S Badve ${ }^{4}$ \\ 'Department of Biopharmaceutical Sciences, University of Illinois at Chicago, Chicago, IL 606 12, USA; ${ }^{2}$ Department of Surgery, Northwestern University, \\ Chicago, IL 6061 I, USA; ${ }^{3}$ Department of Pathology, Northwestern University, Chicago, IL 606 II, USA; ${ }^{4}$ Department of Pathology, Indiana University, \\ Indianapolis, IN 46202, USA
}

We previously reported that stable transfection of protein kinase $C$ alpha (PKC $\alpha$ ) into T47D human breast cancer cells results in tamoxifen (TAM)-resistant tumour growth. Relevance of PKC $\alpha$ expression in clinical specimens was determined by comparing PKC $\alpha$ expression in tumours from patients exhibiting disease recurrence with patients remaining disease-free following TAM treatment. Our results suggest that PKC $\alpha$ expression may predict TAM treatment failure. British Journal of Cancer (2003) 88, |400-|402. doi:I0.I038/sj.bjc.6600923 www.bjcancer.com (c) 2003 Cancer Research UK

Keywords: breast cancer; tamoxifen resistance; protein kinase $\mathrm{C}$ alpha

Resistance to tamoxifen (TAM), the endocrine treatment of choice for all stages of breast cancer, represents a significant clinical problem in the management of the disease. Identification of the key factors involved in the molecular mechanism of TAM resistance will undoubtedly lead to the development of logical therapeutic targets. It is well documented that the oestrogen receptor (ER) and protein kinase $\mathrm{C}$ (PKC) activity and abundance are inversely related in breast cancer cell lines and that PKC is elevated in malignant but not normal breast tissue (Borner et al, 1987; O'Brian et al, 1989; Gordge et al, 1996). Furthermore, increased activator protein-1 (AP-1) activity occurs in hormoneindependent breast cancer cell lines and tumours (Dumont et al, 1996; Johnston et al, 1999; Schiff et al, 2000). Protein kinase C is an upstream activator of the AP-1 pathway. We reported that stable transfection of $\mathrm{PKC} \alpha$ into T47D human breast cancer cells results in a hormone-independent phenotype and TAM-resistant tumour growth (Tonetti et al, 2000). Tumours formed from these cells grow in the presence of TAM and regress upon $17 \beta$-oestradiol (E2) administration (Chisamore et al, 2001). Our finding that both E2 and the pure antioestrogen, ICI 182,780, can inhibit these TAM-resistant tumours may now allow us to predict the efficacy of endocrine therapy. For example, tumours overexpressing $\operatorname{PKC} \alpha$ may be stimulated to grow if the patient is treated with TAM, and therefore a more appropriate therapy may be an oestrogen-like compound or a pure antioestrogen. However, our $\mathrm{T} 47 \mathrm{D} / \mathrm{PKC} \alpha$ tumour model cannot determine whether $\mathrm{PKC} \alpha$ overexpression occurs in patients prior to TAM exposure, or is a result of long-term TAM treatment. To address this question, we identified paired paraffin-embedded tumour blocks from patients with primary and recurrent tumour samples that

*Correspondence: Dr DA Tonetti, Department of Biopharmaceutical Sciences (M/C 865), University of Illinois at Chicago, $833 \mathrm{~S}$. Wood St., Rm 335, Chicago, IL 606I2-723I, USA; E-mail: dtonetti@uic.edu Received 19 July 2002; revised 6 February 2003; accepted 10 February 2003 were available from the database of the Lynn Sage Breast Center of Northwestern Memorial Hospital. In addition, primary biopsies from patients remaining disease-free with at least 5 years of followup were identified. To determine changes, if any, in the intensity and/or incidence of $\mathrm{PKC} \alpha$ expression, immunohistochemistry was performed on all biopsies.

\section{MATERIALS AND METHODS}

\section{Tumour specimens}

Paired paraffin-embedded tumour blocks from 15 patients where primary and recurrent tumour samples were identified from the database of the Lynn Sage Breast Center of Northwestern Memorial Hospital. In addition, 15 primary biopsies from patients remaining disease-free with at least 5 years of follow-up were identified. This study was approved by the Institutional Review Board at Northwestern University Medical School.

\section{Immunohistochemistry}

Sections, $4 \mu \mathrm{m}$ thick, were deparaffinised with $100 \%$ CitriSolv dipped in $100 \%$ ethanol. Endogenous peroxidase activity was blocked with $0.3 \% \mathrm{H}_{2} \mathrm{O}_{2}$ in methanol for $30 \mathrm{~min}$, followed by immersion in graded alcohols. After rinsing in distilled water, antigen retrieval was accomplished by boiling in citrate buffer. After rinsing with PBS, the sections were blocked for $1 \mathrm{~h}$ with normal goat serum. The sections were incubated overnight at $4^{\circ} \mathrm{C}$ with a PKC $\alpha$ primary polyclonal antibody (C-20, Santa Cruz Biotechnology Inc., Santa Cruz, CA, USA). The sections were incubated for $30 \mathrm{~min}$ with biotinylated goat anti-rabbit IgG $(\mathrm{H}+\mathrm{L})$, followed by incubation for 30 min with HRP - Streptavidin (HistoMark Biotin Streptavidin kit; KPL, Gaithersburg, MD, USA). Sections were rinsed with PBS for $5 \mathrm{~min}$ between each reaction. 3,3'-Diaminobenzidine $(\mathrm{DAB}+)$ solution (DAKO, Carpinteria, CA, USA) was used as a chromogen. Finally, sections were 
counterstained with haematoxylin. Stained sections were photographed at $\times 40$ magnification using an Olympus BX40 microscope attached to a SONY DP10 digital camera. Analysis of the entire slide was performed to score the intensity of staining. Intensity was evaluated semiquantitatively by assigning the score of either negative ( 0$)$, weak positive $(1+,<10 \%$ staining), moderate $(2+, 10-30 \%$ staining), or intense $(3+,>30 \%$ staining). The specificity of the staining was ascertained by several methods, including the use of PBS or isotypic nonspecific antibodies in lieu of the specific anti-PKC- $\alpha$ antibody. Dilution experiments using the primary antibody to assess specificity and observe extinction of signal were also performed. In addition, staining with the PKC $\alpha$ antibody was repeated in the presence of a specific PKC $\alpha$ blocking peptide (sc-3007, Santa Cruz, USA). There was no staining of the breast epithelial cells under these conditions.
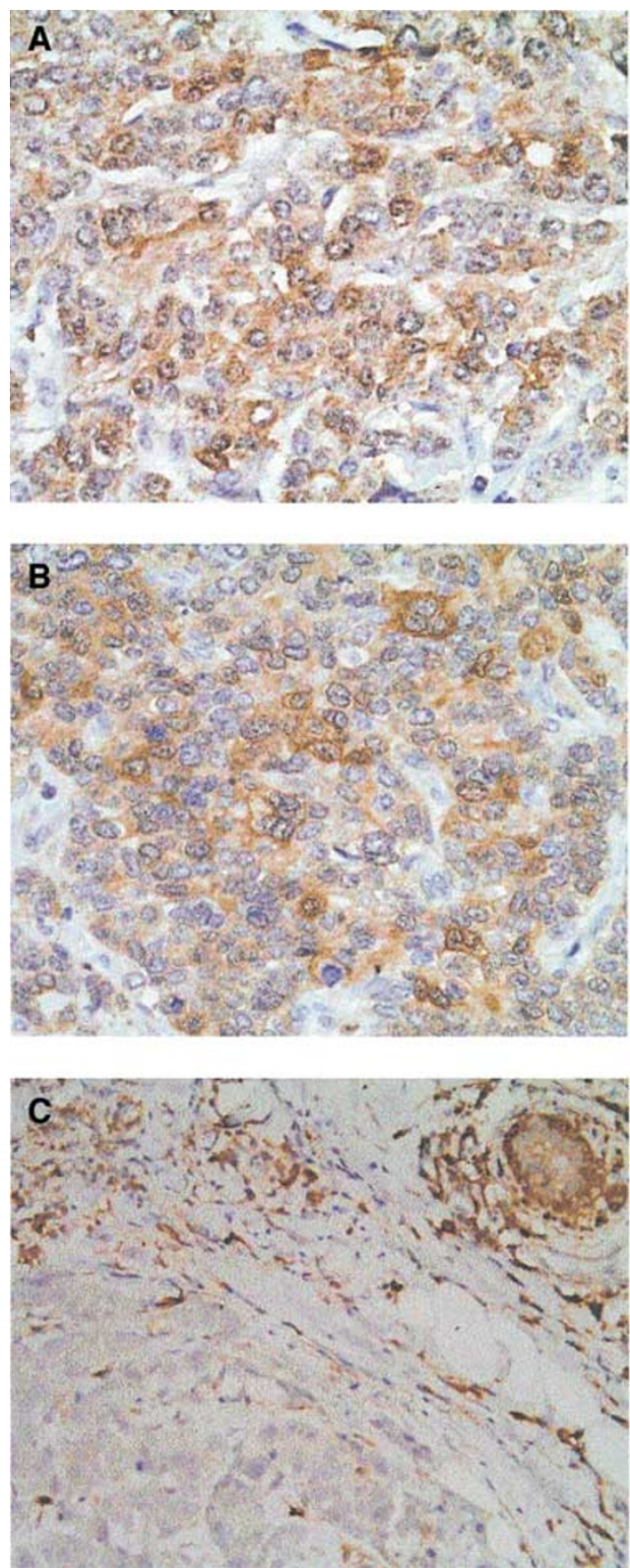

Figure I Protein kinase $C$ alpha immunohistochemical staining of representative patient tumours. (A, B) Matched primary and recurrent biopsies from patient \# I0. (C) Primary biopsy from patient \#4 exhibiting no disease recurrence. Magnification $\times 40$
Table I PKC $\alpha$ immunostaining: patients remaining disease-free

\begin{tabular}{lcccc}
\hline Patient no. & Age $(\mathbf{y})$ & LN $^{\mathbf{a}}+$ /total & Grade & Primary biopsy $^{\mathbf{b}}$ \\
\hline 1 & 87 & $10 / 19$ & 2 & $1+$ \\
2 & 41 & $20 / 21$ & 3 & $1+$ \\
3 & 51 & $0 / 13$ & 1 & 0 \\
4 & 45 & $0 / 18$ & 2 & 0 \\
5 & 54 & $0 / 0$ & 1 & 0 \\
6 & 46 & $7 / 18$ & 3 & 0 \\
7 & 40 & $0 / 18$ & 2 & 0 \\
8 & 35 & $0 / 0$ & 2 & 0 \\
9 & 53 & $0 / 0$ & 2 & 0 \\
10 & 69 & $0 / 0$ & 2 & $1+$ \\
11 & 58 & $0 / 0$ & 3 & 0 \\
12 & 48 & $8 / 20$ & 2 & 0 \\
13 & 50 & $20 / 21$ & 3 & 0 \\
14 & $0 / 0$ & 1 & $2+$ \\
15 & 72 & $0 / 24$ & 3 & $1+$ \\
\hline
\end{tabular}

PKC $\alpha=$ protein kinase $C$ alpha. ${ }^{a} \mathrm{LN}=$ lymph node; ${ }^{\mathrm{b}} 0=$ negative; $1+=<10 \%$ staining; $2+=10-30 \%$ staining; $3+=>30 \%$ staining.

Table 2 PKC $\alpha$ immunostaining: patients exhibiting recurrence

\begin{tabular}{|c|c|c|c|c|c|}
\hline $\begin{array}{l}\text { Patient } \\
\text { no. }\end{array}$ & $\begin{array}{c}\text { Age at } \\
\text { diagnosis }(y)\end{array}$ & $\mathbf{L N}^{\mathrm{a}}+/$ total & Grade & $\begin{array}{l}\text { Primary } \\
\text { biopsy }^{\mathbf{b}}\end{array}$ & $\begin{array}{l}\text { Recurrent } \\
\text { biopsy }^{b}\end{array}$ \\
\hline I & 45 & $0 / 28$ & 3 & 0 & 0 \\
\hline 2 & 36 & $17 / 17$ & 3 & 0 & $1+$ \\
\hline 3 & 49 & 0/0 & 3 & 0 & $1+$ \\
\hline 4 & 36 & $0 / 13$ & 3 & 0 & $1+$ \\
\hline 5 & 40 & $20 / 24$ & 3 & $3+$ & $2+$ \\
\hline 6 & 48 & $0 / 18$ & 3 & $3+$ & $2+$ \\
\hline 7 & 42 & $0 / 11$ & 2 & $3+$ & $3+$ \\
\hline 8 & 60 & $8 / 16$ & 3 & $3+$ & $3+$ \\
\hline 9 & 37 & $0 / 15$ & 3 & $2+$ & $2+$ \\
\hline 10 & 41 & $2 / 14$ & 3 & $3+$ & $3+$ \\
\hline II & 54 & $0 / 0$ & 2 & $2+$ & $2+$ \\
\hline 12 & 56 & $18 / 26$ & 3 & $2+$ & $2+$ \\
\hline 13 & 44 & $0 / 0$ & 2 & $2+$ & $2+$ \\
\hline 14 & 46 & $4 / 8$ & 3 & $2+$ & $2+$ \\
\hline 15 & 30 & $2 / 9$ & 3 & $2+$ & $1+$ \\
\hline
\end{tabular}

\section{RESULTS}

To determine the possible association of PKC $\alpha$ overexpression with the acquisition of TAM resistance, $\mathrm{PKC} \alpha$ expression was assessed by immunohistochemical staining in two patient populations treated with TAM: patients remaining disease-free following TAM treatment and patients exhibiting disease recurrence. Representative immunohistochemical staining of patient tumours demonstrates the cytoplasmic localisation of $\mathrm{PKC} \alpha$ (Figure 1). Seven percent (one out of 15) of patients remaining disease-free exhibited moderate $\mathrm{PKC} \alpha$ staining and the remaining 14 biopsies exhibited negative or weak positive $\mathrm{PKC} \alpha$ immunostaining (Table 1). Seventy-three percent (11 out of 15) of patients exhibiting disease recurrence showed moderate to intense PKC $\alpha$ immunoreactivity in both the primary and recurrent tumour (Table 2). These results suggest that PKC $\alpha$ overexpression is more frequent in primary tumours of patients who experience disease recurrence compared with patients who remain disease-free. Furthermore, PKC $\alpha$ overexpression may be predictive of TAM treatment failure, since expression is high in the primary biopsy and does not increase in the second biopsy following TAM exposure. However, the sample size of this study is small, and the majority of patients who relapse are younger (mean age 44 years) 
and have tumours of higher grade compared with the disease-free patients (mean age 54 years).

\section{DISCUSSION}

The implications for the use of $\mathrm{PKC} \alpha$ overexpression as a predictive tool for improved therapeutic options are based on our T47D/PKC $\alpha$ xenograft model system demonstrating that E2 induces tumour regression (Chisamore et al, 2001). Other examples of E2-induced regression in both tumours and breast cancer cell lines have been described. Similar to the T47D/PKC $\alpha$ tumour, the T61 tumour derived from a primary breast cancer (Brunner et al, 1996) is ovarian-independent and E2 is inhibitory. However, in contrast to the T47D/PKC $\alpha$ tumour, growth of T61 is inhibited by TAM. A cyclical model of hormonal response in MCF7 tumours has been described wherein after 1 year of TAM treatment, tumours are stimulated by both E2 and TAM, but following 5 years of treatment, E2 causes tumour regression (Yao et al, 2000). We have reported that PKC $\alpha$ is overexpressed in MCF7 tumours after different periods of exposures to TAM (1 year and 5 years) (Chisamore et al, 2001). Both the MCF-7-derived E8CASS cell variant (Sonnenschein et al, 1994) and the MCF-7 long-term oestrogen deprived (LTED) cells (Masamura et al, 1995; Shim et al, 2000) were derived by long-term oestrogen deprivation and undergo apoptosis in response to E2 (Song et al, 2000). A recent report demonstrated that E2-induced apoptosis is likely triggered via a Fas-mediated mechanism (Song et al, 2001). T47D L(hE) cells described by Fernandez et al (1998) were cultured in E2-deficient media long term and also exhibit E2-induced growth inhibition.
However, these cells were found to express elevated ER levels with a $\mathrm{C} \rightarrow \mathrm{A}$ transversion resulting in an $\mathrm{H} 513 \mathrm{~N}$ amino-acid change in the ligand-binding domain.

These findings, taken together with our previous observation that $\mathrm{E} 2$ has a novel antitumour effect on $\mathrm{T} 47 \mathrm{D} / \mathrm{PKC} \alpha$ breast tumours (Chisamore et al, 2001), may have important therapeutic implications in the management of breast cancer patients. Elevated tumour expression of $\mathrm{PKC} \alpha$ may predict TAM treatment failure and indicate that an oestrogenic compound may be more efficacious than TAM and perhaps an aromatase inhibitor. A recent updated analysis of diethylstilbestrol (DES) vs TAM for the treatment of postmenopausal metastatic breast cancer indicates that there is survival advantage for women on DES compared to women on TAM (Peethambaram et al, 1999); however, the basis of this survival advantage remains unknown. Perhaps, preselection of a subset of patients who overexpress PKC $\alpha$ may improve upon the outcome of treatment with DES. We are in the process of expanding these studies in a larger population of patients who are matched by age and stage to substantiate these preliminary findings. Examination of a larger patient series will also allow us to address the relations between ER status and PKC $\alpha$ expression as well as between the intensity of PKC $\alpha$ staining and time to disease recurrence.

\section{ACKNOWLEDGEMENTS}

These studies were supported by NIH/NCI Grant R01CA79847 and the Avon Foundation awarded to DAT.

\section{REFERENCES}

Borner C, Wyss R, Regazzi R, Eppenberger U, Fabbro D (1987) Immunological quantitation of phospholipid/ $\mathrm{Ca}^{2+}$-dependent protein kinase of human mammary carcinoma cells: inverse relationship to estrogen receptors. Int J Cancer 40: $344-348$

Brunner N, Spang-Thomsen M, Cullen K (1996) The T61 human breast cancer xenograft: an experimental model of estrogen therapy of breast cancer. Breast Cancer Res Treat 39: 87-92

Chisamore MJ, Ahmed Y, Bentrem DJ, Jordan VC, Tonetti DA (2001) Novel antitumor effect of estradiol in athymic mice injected with a T47d breast cancer cell line overexpressing protein kinase c alpha. Clin Cancer Res 7: $3156-3165$

Dumont JA, Bitonti AJ, Wallace CD, Baumann RJ, Cashman EA, CrossDoersen DE (1996) Progression of MCF-7 breast cancer cells to antiestrogen-resistant phenotype is accompanied by elevated levels of AP-1 DNA-binding activity. Cell Growth Differ 7: $351-359$

Fernandez P, Wilson C, Hoivik D, Safe SH (1998) Altered phenotypic characteristics of T47D human breast cancer cells after prolonged growth in estrogen-deficient medium. Cell Biol Int 22: 623-633

Gordge PC, Hulme MJ, Clegg RA, Miller WR (1996) Elevation of protein kinase $A$ and protein kinase $C$ activities in malignant as compared with normal human breast tissue. Eur J Cancer 32A: 2120-2126

Johnston SR, Lu B, Scott GK, Kushner PJ, Smith IE, Dowsett M, Benz CC (1999) Increased activator protein-1 DNA binding and c-Jun NH2terminal kinase activity in human breast tumors with acquired tamoxifen resistance. Clin Cancer Res 5: 251-256

Masamura S, Santner SJ, Heitjan DF, Santen RJ (1995) Estrogen deprivation causes estradiol hypersensitivity in human breast cancer cells. J Clin Endocrinol Metab 80: 2918-2925

O'Brian C, Vogel VG, Singletary SE, Ward NE (1989) Elevated protein kinase $\mathrm{C}$ expression in human breast tumor biopsies relative to normal breast tissue. Cancer Res 49: 3215-3217
Peethambaram PP, Ingle JN, Suman VJ, Hartmann LC, Loprinzi CL (1999) Randomized trial of diethylstilbestrol $v s$ tamoxifen in postmenopausal women with metastatic breast cancer. An updated analysis. Breast Cancer Res Treat 54: 117-122

Schiff R, Reddy P, Ahotupa M, Coronado-Heinsohn E, Grim M, Hilsenbeck SG, Lawrence R, Deneke S, Herrera R, Chamness GC, Fuqua SA, Brown $\mathrm{PH}$, Osborne CK (2000) Oxidative stress and AP-1 activity in tamoxifenresistant breast tumors in vivo. J Natl Cancer Inst 92: 1926-1934

Shim WS, Conaway M, Masamura S, Yue W, Wang JP, Kmar R, Santen RJ (2000) Estradiol hypersensitivity and mitogen-activated protein kinase expression in long-term estrogen deprived human breast cancer cells in vivo. Endocrinology 141: 396-405

Song R, McPherson R, Yue W, Wang J, Santen R (2000) Estrogen induces apoptosis in human breast cancer cells adapted to long term estrogen deprivation. In American Association for Cancer Research Vol. 41, pp 427 San Francisco, CA

Song RX, Mor G, Naftolin F, McPherson RA, Song J, Zhang Z, Yue W, Wang J, Santen RJ (2001) Effect of long-term estrogen deprivation on apoptotic responses of breast cancer cells to 17beta-estradiol. J Natl Cancer Inst 93: $1714-1723$

Sonnenschein C, Szelei J, Nye TL, Soto AM (1994) Control of cell proliferation of human breast MCF7 cells; serum and estrogen resistant variants. Oncol Res 6: $373-381$

Tonetti DA, Chisamore MJ, Grdina W, Schurz H, Jordan VC (2000) Stable transfection of protein kinase $\mathrm{C}$ alpha $\mathrm{cDNA}$ in hormone-dependent breast cancer cell lines. Br J Cancer 83: 782-791. doi:10:1054/ bjoc. 2000.1326

Yao K, Lee ES, Bentrem DJ, England G, Schafer JI, O’Regan RM, Jordan VC (2000) Antitumor action of physiological estradiol on tamoxifenstimulated breast tumors grown in athymic mice. Clin Cancer Res 6: $2028-2036$ 